\title{
Time Trends of Polybrominated Diphenyl Ethers (PBDEs) in Antarctic Biota
}

\author{
E Markham \\ EK Brault \\ Virginia Institute of Marine Science \\ M Khairy \\ AR Robuck \\ ME Goebel
}

See next page for additional authors

Follow this and additional works at: https://scholarworks.wm.edu/vimsarticles

Part of the Aquaculture and Fisheries Commons

\section{Recommended Citation}

Markham, E; Brault, EK; Khairy, M; Robuck, AR; Goebel, ME; Cantwell, MG; Dickhut, RM; and Lohmann, R, Time Trends of Polybrominated Diphenyl Ethers (PBDEs) in Antarctic Biota (2018). Acs Omega, 3(6), 6595-6604.

10.1021/acsomega.8b00440

This Article is brought to you for free and open access by the Virginia Institute of Marine Science at W\&M ScholarWorks. It has been accepted for inclusion in VIMS Articles by an authorized administrator of W\&M ScholarWorks. For more information, please contact scholarworks@wm.edu. 


\section{Authors}

E Markham, EK Brault, M Khairy, AR Robuck, ME Goebel, MG Cantwell, RM Dickhut, and R Lohmann 


\title{
Time Trends of Polybrominated Diphenyl Ethers (PBDEs) in Antarctic Biota
}

\author{
Erin Markham, ${ }^{\dagger}$ Emily K. Brault, ${ }^{\ddagger}, \#$ Mohammed Khairy, ${ }^{\dagger, \nabla}$ Anna R. Robuck, ${ }^{\dagger}$ Michael E. Goebel, ${ }^{\S}$ \\ Mark G. Cantwell," Rebecca M. Dickhut, ${ }^{\sharp, \perp}$ and Rainer Lohmann ${ }^{* \dagger \oplus}$ \\ ${ }^{\dagger}$ Graduate School of Oceanography, University of Rhode Island, 215 South Ferry Road, Narragansett, Rhode Island 02882, United \\ States \\ ${ }^{\ddagger}$ Virginia Institute of Marine Science, 1208 Greate Road, Gloucester Point, Virginia 23062, United States \\ ${ }^{\S}$ Antarctic Ecosystem Research Division, NOAA Fisheries, Southwest Fisheries Science Center, 8901 La Jolla Shores Drive, La Jolla, \\ California 92037, United States \\ "Atlantic Ecology Division, U.S. Environmental Protection Agency, Narragansett, Rhode Island 02882, United States
}

\section{Supporting Information}

\begin{abstract}
Polybrominated diphenyl ethers (PBDEs) are "emerged" contaminants that were produced and used as flame retardants in numerous consumer and industrial applications for decades until banned. They remain ubiquitously present in the environment today. Here, a unique set of $>200$ biotic samples from the Antarctic was analyzed for PBDEs, including phytoplankton, krill, fish, and fur seal milk, spanning several sampling seasons over 14 years. PBDE-47 and -99 were the dominant congeners determined in all samples, constituting $>60 \%$ of total PBDEs. A temporal trend was observed for $\sum_{7} \mathrm{PBDE}$ concentrations in fur seal milk, where concentrations significantly increased $\left(R^{2}=0.57, p<0.05\right)$ over time $(2000-2014)$. Results for krill and phytoplankton also suggested increasing PBDE concentrations over time. Trends of PBDEs in fur seal milk of individual seals sampled 1 or more years apart showed no clear temporal trends. Overall, there was no indication of PBDEs decreasing in Antarctic biota yet, whereas numerous studies have reported decreasing trends in the northern hemisphere. Similar PBDE concentrations in perinatal versus nonperinatal milk implied the importance of local PBDE sources for bioaccumulation. These results indicate the need for continued assessment of contaminant trends, such as PBDEs, and their replacements, in Antarctica.
\end{abstract}

\section{INTRODUCTION}

Antarctica is one of the most pristine places on the planet. However, even in this remote region, anthropogenic effects are measurable. Scientific exploration in Antarctica has occurred for decades and in the summer season, the continent hosts over 100 active facilities operated by 30 different nations. ${ }^{1}$ Although pollution in Antarctica has typically been orders of magnitude lower than concentrations reported elsewhere around the globe, organic contaminants, particularly (semi-) volatile ones, have reached the region via long-range environmental transport by processes of global fractionation and cold condensation. ${ }^{2}$ Legacy contaminants, such as polychlorinated biphenyls (PCBs) and organochlorine pesticides (OCPs), have been reported along with more recent contaminants, such as polybrominated diphenyl ethers (PBDEs) and perfluoroalkyl substances, in numerous environmental matrices from the region. ${ }^{3-9}$ Some of this contamination has also been found to originate from research stations themselves. ${ }^{10,11}$

Polybrominated diphenyl ethers are "emerged" contaminants that have been used as additive flame retardants for decades in a wide range of consumer and industrial applications (e.g., upholstery, electronics) and are easily leached from these manufactured goods into the environment, food webs, and ultimately reaching humans. ${ }^{12}$ PBDEs, like many legacy persistent organic pollutants (POPs) (e.g., PCBs), are hydrophobic and lipophilic. The height of PBDE production was dominated by three different commercial mixtures (penta-, octa-, and deca-BDE). ${ }^{13}$ In 2009, penta- and octa-PBDE mixtures were listed by the Stockholm Convention. ${ }^{13}$ However, production of the deca-BDE has persisted in many countries and a massive reserve of products that contain PBDEs exist around the globe and will continue to leach them into the environment. $^{5,14-16}$

Several studies have reported PBDE concentrations starting to decrease over the last 5-10 years. For example, time trends of PBDEs in samples collected from Swedish mothers indicate a decreasing trend for most PBDEs, except for BDEs 153 and 209, from 1996 to $2010 .{ }^{17}$ PBDEs also decreased in Baltic

Received: April 6, 2018

Accepted: June 1, 2018

Published: June 19, 2018 


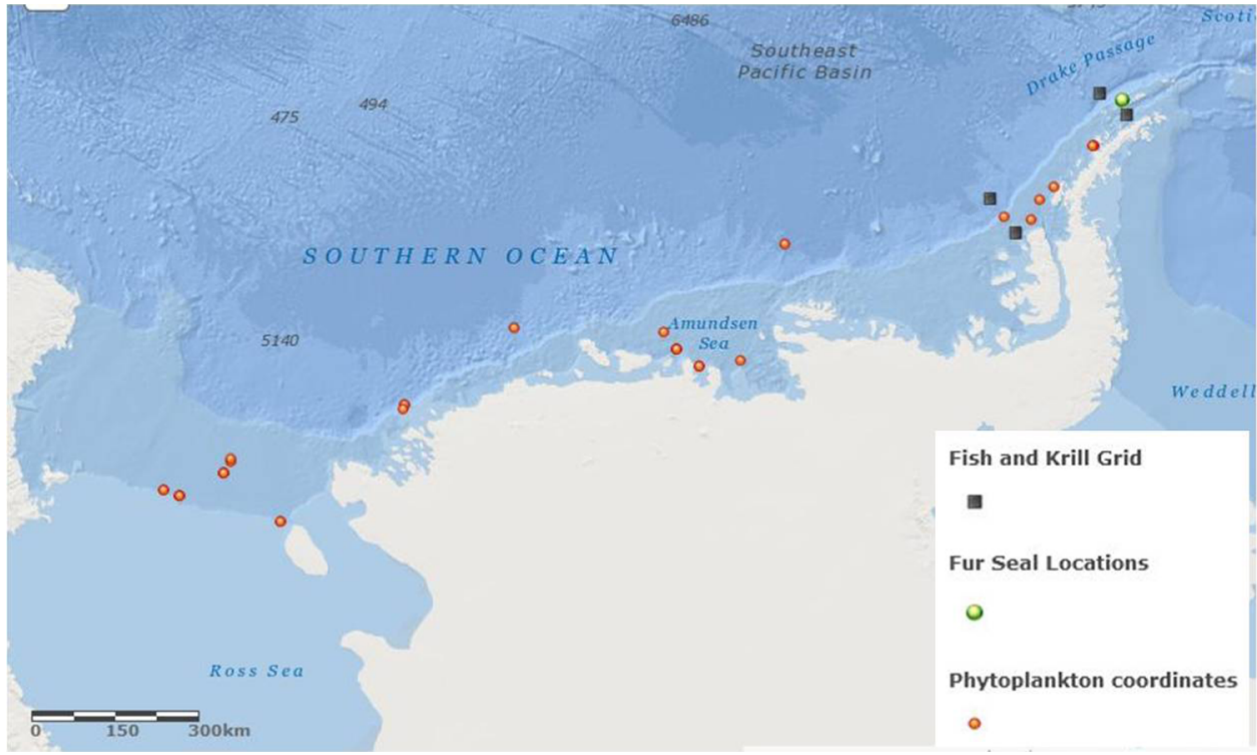

Figure 1. Map of sampling locations. Black squares denote the boundaries of the Long Term Ecological Research (LTER) grid. Created with ArcGIS Explorer.

herring over the last decade. ${ }^{18}$ Across the Great Lakes in North America, PBDEs in fish started to decline in $1999-2000 .{ }^{19}$ So far, no consistent set of Antarctic samples has been available to document time trends of PBDEs in Antarctic marine biota, although several previous studies have detected PBDEs in the Antarctic environment. ${ }^{3,4,9,10,20}$

Kelly et al. in 2008 presented evidence from a Canadian Arctic marine food web in which many PBDEs appeared to exhibit negligible biomagnification, with the exception of BDE47, which did demonstrate food web biomagnification, albeit at a much lower level than PCBs. ${ }^{21}$ Yet in the same study, PBDEs in macroalgae were excluded from the trophic magnification factor calculation as their concentrations exceeded those from other trophic levels by 5-10 times.

We obtained a unique set of biotic samples from West Antarctica (Figure 1), including phytoplankton, krill, fish, and fur seal milk, spanning several years (2000-2014). A previous paper reported generally declining trends of several but not all PCBs and legacy OCPs in these fur seal milk samples; PBDE concentrations were not measured at the time. ${ }^{6}$ We used these samples to assess the presence and trophic transfer of PBDEs in the West Antarctic food web and to identify the PBDE temporal trends in this region either from yearly averages or in the case of repeatedly sampled fur seals, from individual trends over time. The food web structure was assessed using stable isotopes of carbon $\left(\delta^{13} \mathrm{C}\right)$ and nitrogen $\left(\delta^{15} \mathrm{~N}\right)$.

Specific goals in this research were to (i) determine which PBDEs are being detected in different Antarctic biota; (ii) establish temporal trends of common PBDE congeners over a time period where global regulations and restrictions on production had been implemented (i.e., 2000s); (iii) contrast trends of PBDEs in Antarctic fur seal milk to those from the Arctic; and (iv) assess the difference of milk sampled before and after fur seals begin foraging locally in waters off the Antarctic Peninsula.

\section{MATERIALS AND METHODS}

Sample Collection. Milk samples were collected from Antarctic fur seals (Arctocephalus gazella) approximately 100 $\mathrm{km}$ off the Antarctic Peninsula at Cape Shirreff, Livingston Island $\left(62.47^{\circ} \mathrm{S}, 60.77^{\circ} \mathrm{W}\right)$ over the austral summers of $2000 /$ 2001, 2001/2002, 2004/2005, 2009/2010, 2010/2011, 2011/ 2012, 2012/2013, and 2013/2014 (Figure 1 and Tables S1S8). Most seals were multiparous females in their perinatal stage (i.e., the seals had all bred prior to the year of sample collection and milk was collected during the perinatal period, 1-2 days postpartum, prior to initiation of offshore foraging trips), except for the 2011/2012, 2012/2013, and 2013/2014 samples, which consisted of both perinatal and nonperinatal (i.e., after initiation of foraging cycles) milk samples (Tables S6-S8). Seals were assumed to have had at least one pup prior to the breeding season sampled as all seals were age 5 or older, with the majority being over the age of 7 . Seal capture was performed following methods described in Polito and Goebel and as reported in Brault et al. ${ }^{6,22}$ In brief, seals were captured with hoop nets, sedated with $5 \mathrm{mg}$ of midazolam, and anesthetized with isoflurane. Milk was collected after an intramuscular injection of oxytocin $(0.25 \mathrm{~mL}, 10 \mathrm{UI} / \mathrm{mL})$ in precleaned vials and stored at $-20{ }^{\circ} \mathrm{C}$ until analysis. ${ }^{6,22}$ Temperature loggers sampling every $10 \mathrm{~min}$ were kept with samples to confirm storage temperature.

Phytoplankton samples were collected in a region of Antarctica that spans from the West Antarctic Peninsula to the Ross Sea $\left(64.78^{\circ} \mathrm{S}, 64.07^{\circ} \mathrm{W}\right.$ to $78.64^{\circ} \mathrm{S}, 164.30^{\circ} \mathrm{W}$, Figure 1 ) over the austral summers of $2007 / 2008,2009 / 2010$, and 2010/2011 using ring net tows (Table S9). Phytoplankton samples consisted largely of diatoms (Antarctic Peninsula) and Phaeocystis sp. (Amundsen and Ross Seas). Further specifics on sample collection can be referenced in Brault et al. ${ }^{6,23}$

All krill and fish samples were collected from within the Palmer Long Term Ecological Research (LTER) grid survey region (approx. $66.99^{\circ} \mathrm{S}, 69.28^{\circ} \mathrm{W}$ to $61.94^{\circ} \mathrm{S}, 73.78^{\circ} \mathrm{W}$, Figure 1) via $700 \mu \mathrm{m}$ ring net tows (taken at oblique angles, Table S10). Krill samples consisted predominantly of Euphausia superba and were collected during the austral summers of 2007/ 2008 and 2010/2011 and split into three size classes (juveniles, adults (including mature females), and gravid females). Fish samples consisted of either silverfish (Pleuragramma antarcti- 
Table 1. Comparison of Average PBDE Concentrations in Antarctic Biota (ng/g lipid) \pm 1 Standard Deviation from This and Previous Studies

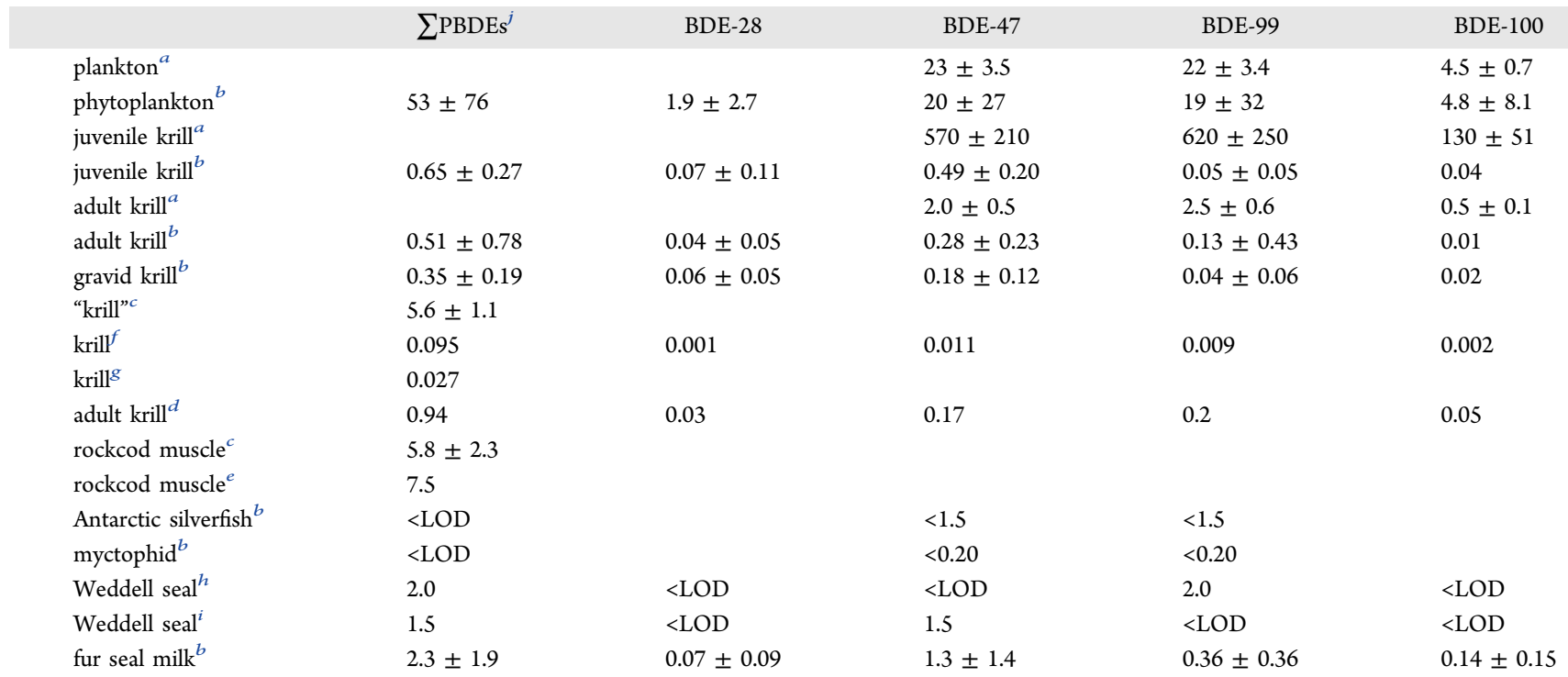

${ }^{a}$ Chiuchiolo et al., ${ }^{5} 64.7^{\circ} \mathrm{S}, 64.0^{\circ} \mathrm{W} .{ }^{b}$ This study, $\sum_{7}$ BDEs, Ross Sea to Antarctic Peninsula; results were averaged over all sampling seasons. ${ }^{c}$ Corsolini et al., ${ }^{4}$ Ross Sea, approx. $74^{\circ} 04^{\prime}$ S, $179^{\circ} 06^{\prime}$ E. ${ }^{d}$ Bengtson Nash et al., ${ }^{25}$ arithmetic means, $\sim 63-69^{\circ} \mathrm{S}, 30-80^{\circ} \mathrm{E} .{ }^{e}$ Cincinelli et al., ${ }^{\circ}$ assuming $1 \%$ lipid content. ${ }^{f}$ Galbán-Malagón et al., ${ }^{26}$ mean values; around the Antarctic peninsula. ${ }^{g}$ Corsolini et al. ${ }^{27}$ mean values, Ross Sea, based on $3.6 \%$ lipid content. ${ }^{h}$ Cipro et al., ${ }^{28}$ Weddell seal blubber from King George Island $\left(62^{\circ} 050^{\prime} \mathrm{S}, 58^{\circ} 230^{\prime} \mathrm{W}\right) .{ }^{i}$ Trumble et al., ${ }^{29}$ adult Weddell seal blubber near McMurdo Station, Antarctica $\left(77^{\circ} 55^{\prime} \mathrm{S}, 166^{\circ} 39^{\prime} \mathrm{E}\right) .{ }^{j}$ Note that the number of BDE congeners included in the $\sum$ PBDEs varies between studies.

cum) or myctophids (Electrona antarctica) and were collected in the same manner as krill (Table S11).

Sample Extraction. Fur seal milk extraction was conducted in two batches. The first batch $(n=59)$, which consists of samples from the five austral summers spanning from 2000/ 2001 to 2010/2011, was extracted at the Virginia Institute of Marine Science (VIMS) following previously established POP procedures as reported in Geisz et al. ${ }^{24}$ In short, fur seal milk was freeze-dried, homogenized, subsampled ( $1 \mathrm{~g}$ of dry weight), solvent-extracted (65:35 dichloromethane/acetone), and analyzed for several POPs (e.g., 1,1,1-trichloro-2,2-bis ( $p$ chlorophenyl)ethane (DDT), PCBs, and chlordane) as well as lipid content. ${ }^{6}$ Sample extracts were shipped to the University of Rhode Island's Graduate School of Oceanography (URI-GSO) for PBDE analysis.

The second batch of fur seal milk samples (samples from $2011 / 2012,2012 / 2013$, and $2013 / 2014, n=71$ ) was extracted at URI-GSO, as detailed in the Supporting information (SI). Briefly, $2 \mathrm{~mL}$ of fur seal milk was spiked with PBDE surrogates, extracted three times with $20 \mathrm{~mL}$ each of $n$-hexane/acetone (2:1), treated with concentrated sulfuric acid to denature lipids, and cleaned on solid-phase extraction cartridges. Percent lipid was measured separately.

Phytoplankton, fish, and krill samples were also extracted at VIMS. Samples were manually homogenized with a Virtis " $45^{\text {" }}$ tissue homogenizer (Virtis Co. Inc.), freeze-dried at $-80{ }^{\circ} \mathrm{C}$ for approximately $72 \mathrm{~h}$, and solvent-extracted. Further details on sample preparation can be gathered from Brault. ${ }^{23}$ Following analysis at VIMS for several legacy POPs, ${ }^{6}$ phytoplankton, fish, and krill, sample extracts were shipped to URI-GSO to be analyzed for PBDEs.

PBDE Analysis. All samples were analyzed for monothrough hepta-brominated congeners (BDE-2, -8, -15, -30, -28, $-49,-47,-100,-99,-154,-153$, and -183) via gas chromatography (GC) tandem mass spectrometry (MS) on an Agilent 6890N GC coupled to a Waters Quattro Micro MS/ MS under electron ionization/MS/MS in multiple reaction monitoring mode using a DB-5MS column (Agilent J\&W GC Columns, 122-5532, length $30 \mathrm{~m}$, i.d. $0.250 \mathrm{~mm}$, film $0.25 \mu \mathrm{m}$ ) and splitless injection (for more details, see SI). Analysis of BDE-209 was conducted separately, and procedures are detailed in the SI.

Sample extracts were spiked with $10 \mu \mathrm{L}$ of a $5 \mathrm{ng} / \mu \mathrm{L}^{13} \mathrm{C}_{12^{-}}$ labeled PBDE surrogate $\left({ }^{13} \mathrm{C}_{12}\right.$ BDEs-28, 47, 99, 153, and 183, Cambridge Isotope Laboratories) for a total concentration of $50 \mathrm{ng}$ and $5.0 \mu \mathrm{L}$ of a $5.0 \mathrm{ng} / \mu \mathrm{L}$ injection standard ( $p$ terphenyl- $d_{14}$, AccuStandard) for a total concentration of $25 \mathrm{ng}$. To the samples originally extracted at VIMS, the surrogate was added postextraction. These samples were corrected for the average recoveries of previously analyzed POPs (e.g., DDT, PCBs, and chlordane), which were $79 \pm 3.7 \%$ for phytoplankton, $69 \pm 1.8 \%$ for krill, and $78 \pm 1.8 \%$ for fur seal milk. The second batch of fur seal milk samples (2011/ 2012, 2012/2013, and 2013/2014) was spiked prior to extraction at URI-GSO directly with $20 \mu \mathrm{L}$ of a $2.0 \mathrm{ng} / \mu \mathrm{L}$ PBDE surrogate standard in nonane. Results presented below are only for compounds that were detected $>30 \%$ of the time.

Quality Control. Laboratory blanks of a hydromatrix material were initially extracted alongside real samples, and any blanks included in the vial files for shipment from VIMS to URI-GSO were analyzed for PBDEs. All samples were blankcorrected; main detected congeners were BDE-47 and -99 with concentrations averaging $0.18 \pm 0.20 \mathrm{ng}$ (standard deviation (SD) ) and $0.18 \pm 0.23 \mathrm{ng}$, respectively (Table S12, SI). For BDE-209, amounts in blanks were similar to fur seal milk results, so results are not reported here.

At URI-GSO, laboratory blanks, matrix spikes $(n=8)$, blank spikes $(n=4)$, and duplicates of fur seal milk $(n=10)$ were included. Limit of detection (LOD) was calculated as the average detected blank concentrations +3 times the standard 

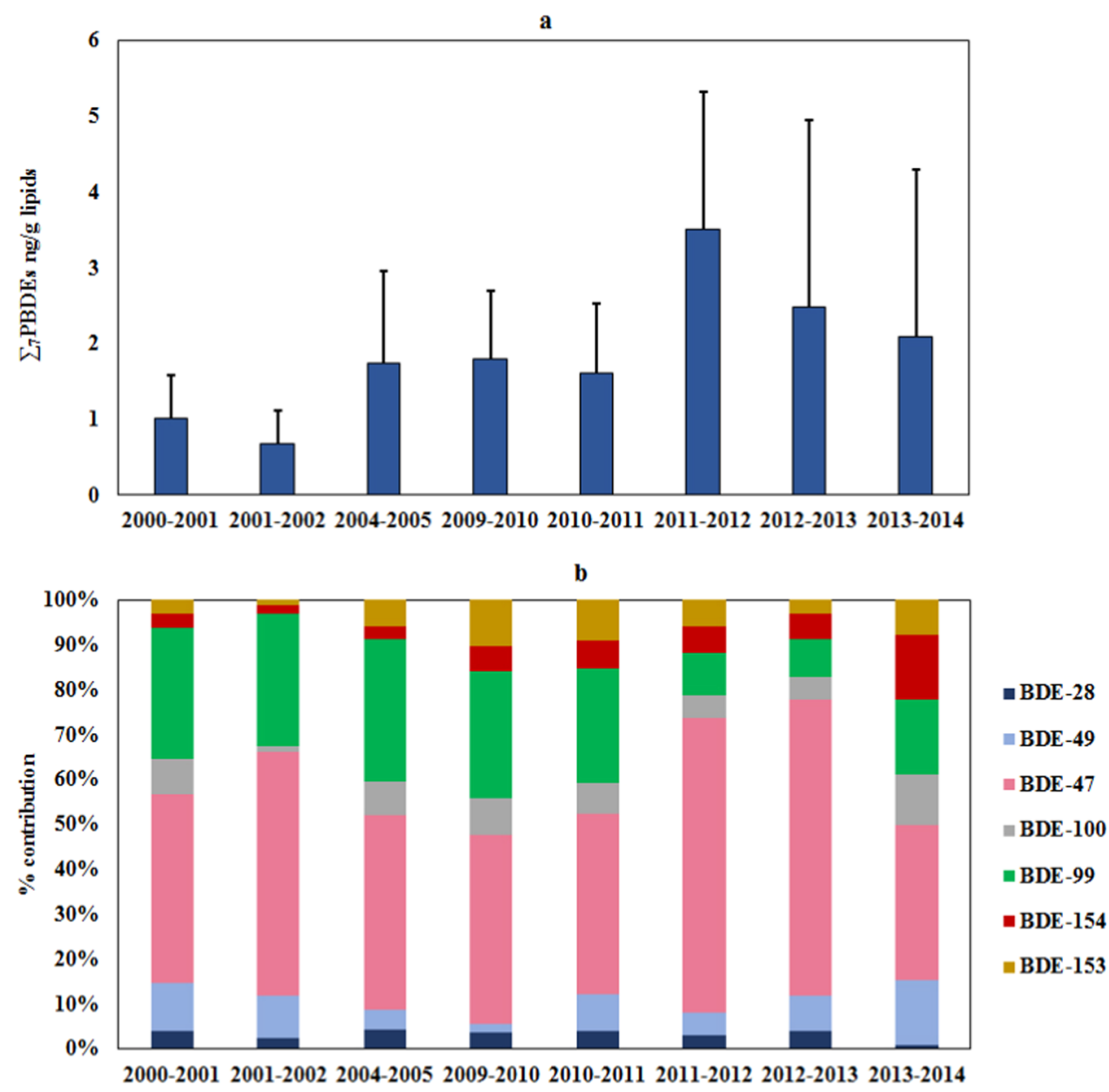

Figure 2. (a) Average sum of PBDEs per breeding season for the eight nonconsecutive austral summers sampled. Bars represent standard deviation. The first five austral summers (2000/2001-2010/2011) have had a recovery correction of $77.86 \%$ applied. (b) Average percent composition of PBDEs in fur seal milk from 2000/2001 to 2013/2014.

deviation (Table S13). For congeners that were not detected, the noise was used to derive LODs (Table S14); LODs ranged from $0.011 \mathrm{ng} / \mathrm{g}$ lipid (BDE-2, 15) to $0.16 \mathrm{ng} / \mathrm{g}$ lipid (BDE$99)$. Recoveries of the surrogate standards ranged from $83 \pm$ $2.4 \%$ (BDE-183) to $94 \pm 3.1 \%$ (BDE-47). Recoveries of the congeners in the matrix and blank spikes generally ranged from 92\% (BDE-2) to $102 \%$ (BDE-47), as shown in Table S15. Relative percent difference for the duplicates ranged from $6.2 \%$ (BDE-100) to 21\% (BDE-2).

$\delta^{13} \mathrm{C}$ and $\delta^{15} \mathrm{~N}$ Analysis. $\delta^{13} \mathrm{C}$ and $\delta^{15} \mathrm{~N}$ stable isotopes for the majority of samples were determined via an elemental analyzer isotopic ratio mass spectrometer at VIMS, as described elsewhere (Figure S1). ${ }^{6}$ Some plankton samples were analyzed at the University of California, Santa Cruz (UCSC) on a Carlo Erba EA 1108 elemental analyzer coupled to a Finnegan DeltaPlus isotopic ratio mass spectrometer. Average values were -29 $\pm 0.40 \%$ or for $\delta^{13} \mathrm{C}$ and $1.6 \pm 0.50 \%$ o for $\delta^{15} \mathrm{~N}$.

Statistical Analysis. Data were tested for normality using the Shapiro-Wilks test in RStudio, IBM SPSS Statistics 22, and SigmaPlot 12 software packages. Concentrations were natural log transformed to make data have a normal or near-normal distribution. Linear regressions were performed for each congener with $>30 \%$ detection against fur seal age, breeding season, $\delta^{13} \mathrm{C}$, and $\delta^{15} \mathrm{~N}$. Any difference between PBDE concentrations in perinatal and nonperinatal milk was tested using a student's two-sample $t$ test assuming unequal variances.
A student's $t$ test was used to compare between detected PBDE concentrations in the krill samples of 2007 and 2011. Similarly, the one-way repeated analysis of variance (ANOVA) test was used to compare between detected PBDE concentrations in (i) the different krill samples (juveniles, adults, and gravid); (ii) phytoplankton samples collected in 2007-2011; and (iii) between the calculated trophic levels for the different seal samples collected in 2000, 2001, 2004, 2009, and 2010.

\section{RESULTS AND DISCUSSION}

PBDE-47 and -99 were the dominant congeners determined in all samples, generally constituting $>60 \%$ of total PBDEs. Phytoplankton samples displayed the highest overall concentrations, followed by fur seal milk, krill, and lastly fish, in which no PBDEs were detected (Table 1). The lower brominated congeners (BDE-2, -8, -15, and -30) and BDE-183 were not regularly detected until 2011/2012. These trends could, at least partially, be explained by the switch in extraction procedures between VIMS (2000/2001-2010/2011) and URI-GSO. To ensure consistency across the various samples, we focus on the seven most routinely detected congeners (BDE-28, -49, -47, $-100,-99,-154$, and -153), which were also summed ( $\left.\sum_{7} \mathrm{BDEs}\right)$.

Fur Seal Milk. Lipids in fur seal milk were high with an average value of $64 \pm 9 \%$ (SD; range $14-84 \%$ ). PBDEs were detected in all fur seal milk samples $(n=130$; Tables S15- 


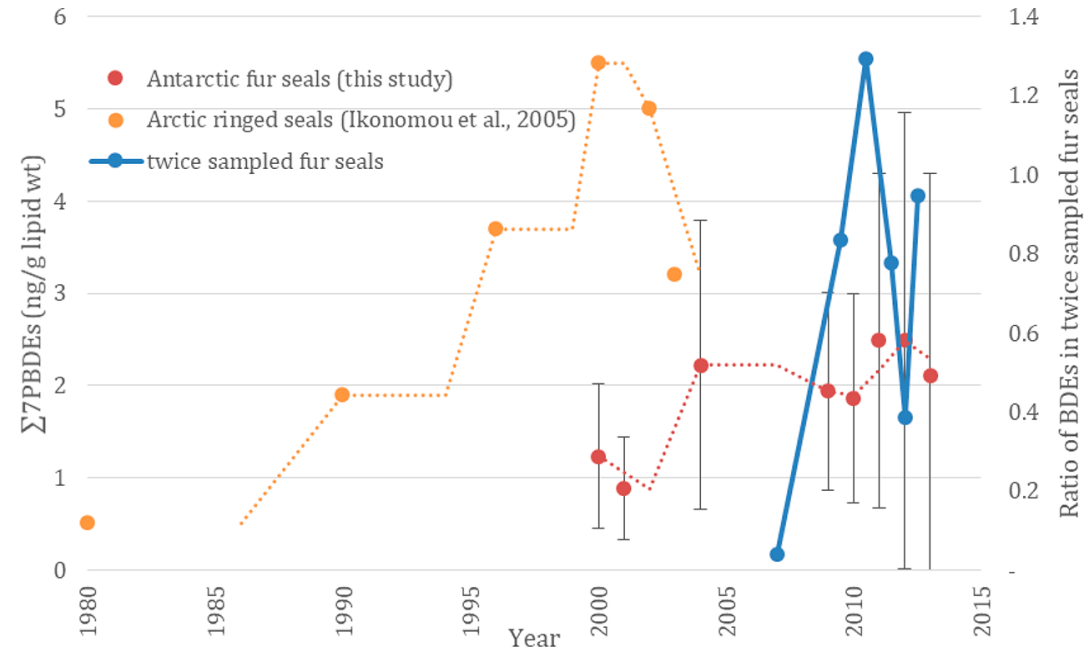

Figure 3. $\sum_{7} \mathrm{PBDE}$ trends in Arctic fur seals (red dotted line), reported BDE concentrations in Arctic ringed seals (orange dashed line, both left axis), and ratios of BDE concentrations in fur seal milk sampled twice over several years (blue solid line).

S22). The $\sum_{7}$ PBDEs in all fur seal milk samples ranged from 0.14 to $17 \mathrm{ng} / \mathrm{g}$ lipid with a mean $\pm \mathrm{SD}$ of $2.1 \pm 1.9 \mathrm{ng} / \mathrm{g}$ lipid (median of $1.7 \mathrm{ng} / \mathrm{g}$ lipid). BDE-47 was the most dominant congener with a range of $0.14-12 \mathrm{ng} / \mathrm{g}$ lipid and a mean of 1.3 $\pm 1.4 \mathrm{ng} / \mathrm{g}$ lipid (median of $0.95 \mathrm{ng} / \mathrm{g}$ lipid). BDE-99 was the second most dominant congener but showed less variability with a range from $<$ LOD to $2.7 \mathrm{ng} / \mathrm{g}$ lipid, mean of $0.36 \pm 0.36$ $\mathrm{ng} / \mathrm{g}$ lipid (median of $0.27 \mathrm{ng} / \mathrm{g}$ lipid). Similar PBDE concentrations of around 1.5-2.0 ng/g lipid (Table 1) have been reported for Antarctic Weddell seal blubber. ${ }^{28,29}$ For comparison, ringed seal blubber in the Canadian Arctic contained more elevated $\sum_{15}$ PBDEs at $11-14 \mathrm{ng} / \mathrm{g}$ lipid. ${ }^{30}$

Stable isotope analysis was only available for fur seal milk collected during the first five austral summers (2000/20012010/2011, $n=59$ ). Both $\delta^{13} \mathrm{C}$ and $\delta^{15} \mathrm{~N}$ demonstrated variability: $\delta^{13} \mathrm{C}$ ranged from -26 to $-20 \%$ with a mean $\pm \mathrm{SD}$ of $-23 \pm 1.4 \%$; $\delta^{15} \mathrm{~N}$ ranged from 8.0 to $14 \%$, with a mean \pm $\mathrm{SD}$ of $10 \pm 1.2 \%$.

Fur Seal Milk Trends. In fur seal milk, the dominant congeners BDE-47 and -99 showed no significant correlation with age, similar to results for legacy POPs, implying that older animals did not display greater concentrations. ${ }^{6}$ No significant relationships were found between fur seal milk PBDE concentration and $\delta^{13} \mathrm{C}$ value from regression analysis. Few significant trends were observed between PBDE concentration and $\delta^{15} \mathrm{~N}$ value; most notably in 2000/2001, BDE-47 and $\sum_{7} \mathrm{PBDEs}$ versus $\delta^{15} \mathrm{~N}$ both demonstrate significantly negative trends (i.e., decreasing concentration with increasing $\delta^{15} \mathrm{~N}$ value or trophic level). We have no explanation for this trend, but note that it disappears when looking at all fur seal milk results from $2000 / 2001$ to $2010 / 2011$ combined.

$\sum_{7} \mathrm{PBDE}$ concentrations for the $2011 / 2012$ breeding season were significantly greater than for the other breeding seasons, except for 2009/2010 and 2013/2014 (one-way repeated ANOVA, $p<0.001)$. Additionally, a temporal trend was observed for $\sum_{7}$ PBDE concentrations (Figure 2), where concentrations significantly increased $\left(R^{2}=0.57, p=0.03\right)$ over time (from 2000 to 2014). We note that the (increasing) slope of PBDE concentrations over time was not significantly different when considering either all 8 sampling years or just the first 5 years (those extracted at the VIMS).
Fur Seal Milk Trends in the Same Individuals. The previous discussion was based on average values from randomly sampled female fur seals over time. Milk samples from 18 of these individuals were collected twice with at least 1 year between sampling times. From 11 seals, only perinatal milk was obtained, from 3 seals only nonperinatal milk was obtained, and from four seals both perinatal and nonperinatal milk was obtained. Ratios for individual BDE congeners were calculated as the more recent concentration divided by the previous concentrations (Figure S3). No clear trends of changes in PBDE concentrations over time were discernible across all paired milk samples. These results contrast with time trends observed for PBDEs in the northern hemisphere.

In the Great Lakes, PBDE concentrations in fish peaked mostly from 1999 to $2000 .{ }^{19}$ Further away from source regions, PBDE concentrations in ringed seals in East Greenland started to decrease in the early $2000 \mathrm{~s},{ }^{30}$ a trend reported for most Arctic biota. ${ }^{31}$ PBDEs also decreased in Canadian seabirds with a significant and rapid decline after $2003 .{ }^{32}$ An analysis of PBDE mass flows in the U.S. and Canada predicted penta and octa-BDEs stocks to peak in their use around 2004, whereas BDE-209 stock peaked in 2008. ${ }^{15}$ These diverging trends between the northern hemisphere and our results for the Western Antarctic suggest that transport of PBDEs to the remote Southern Hemisphere has been delayed by a decade or so relative to the Arctic region, which is closer to the primary source region (Figure 3). The vast majority of PBDEs were produced and used in the northern hemisphere; ${ }^{33}$ while they are certainly present in the southern hemisphere, it is unclear whether PBDEs in Antarctica are predominantly reflecting southern or northern hemisphere sources.

Perinatal vs Nonperinatal Milk. After breeding, female fur seals from Cape Shirreff spend up to 8 months away at one of three foraging grounds (off the Chilean coast, Patagonian shelf break, or around South Georgia) during the austral winter. ${ }^{34}$ Perinatal milk thus represents PBDEs accumulated during the winter migration. In contrast, nonperinatal milk reflects PBDEs accumulated while foraging offshore Cape Shirreff's breeding beaches and any mobilization of PBDEs from lipid reserves. Across all fur seal milk samples, there were few significant differences in PBDE concentrations between perinatal and nonperinatal milk. The exception was for the 2012/2013 


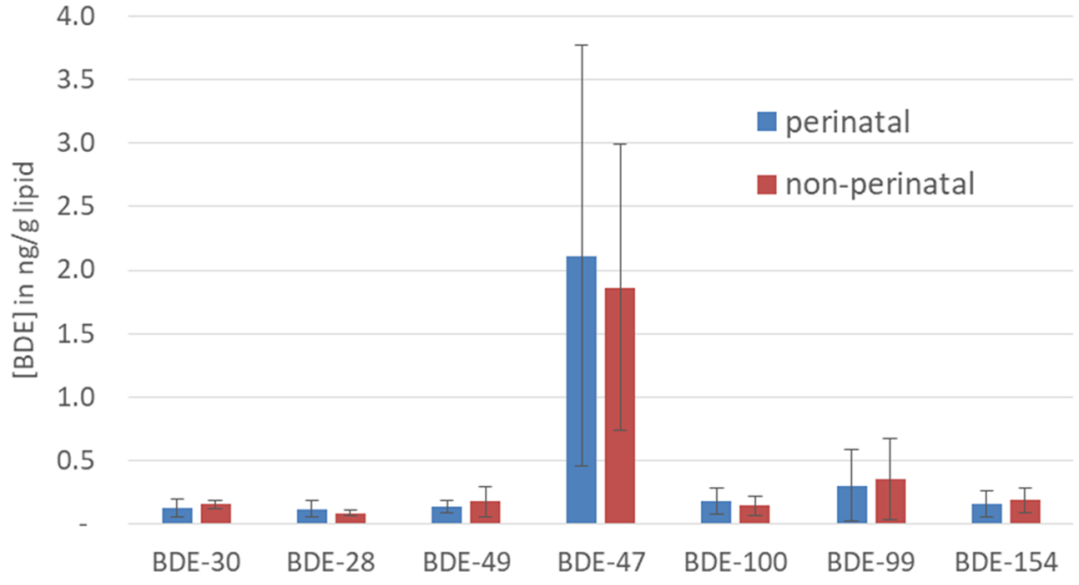

Figure 4. Comparison of BDE concentrations in perinatal and nonperinatal milk sampled from fur seals sampled twice during the same season $(n=$ 10). Error bars represent one standard deviation.

(a)

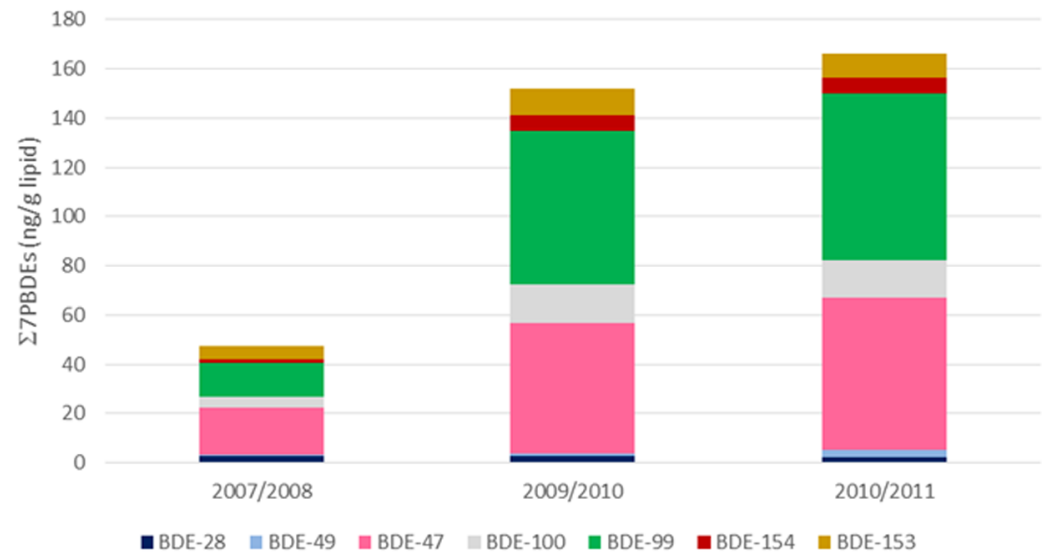

(b)

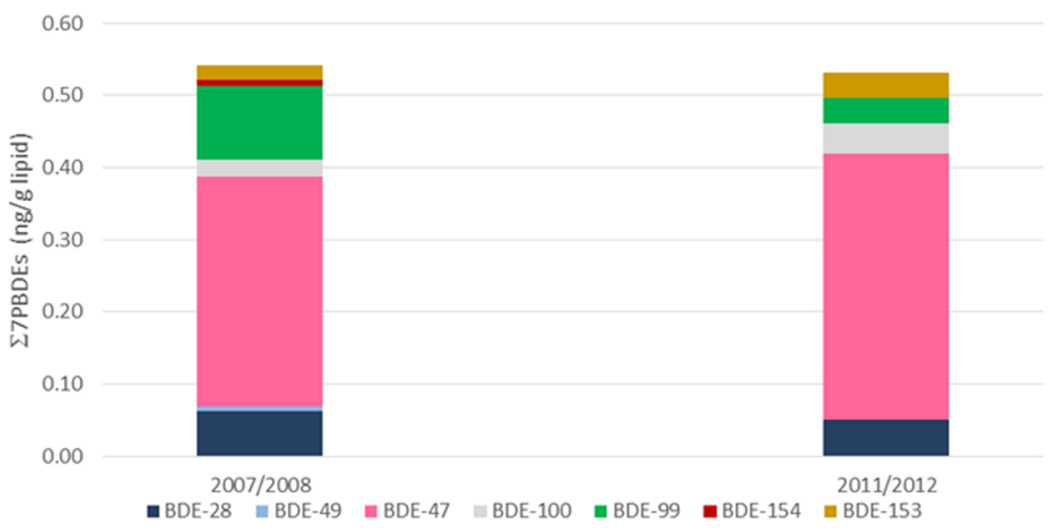

Figure 5. Average $\sum$ PBDEs (ng/g lipid) in (a) phytoplankton and (b) krill per sampling season. Note the uneven interval between years.

sampling period, in which mean \pm SD concentrations of BDE$49(0.33 \pm 0.34 \mathrm{ng} / \mathrm{g}$ lipid $)$ and BDE-99 $(0.28 \pm 0.19 \mathrm{ng} / \mathrm{g}$ lipid) in nonperinatal milk were significantly higher than those in perinatal milk $(0.19 \pm 0.15$ and $0.15 \pm 0.10 \mathrm{ng} / \mathrm{g}$ lipid, respectively; Mann-Whitney rank sum test $p<0.05)$. This is consistent with expectations based on the maternal body burden of lipid-bound pollutants being passed onto the pup during lactation, particularly in the case of the first pup. ${ }^{35}$
The previous discussion was based on average values from randomly milked fur seals both perinatally and nonperinatally. Again, milk from several fur seals was sampled twice during the same season ( $n=10$ : nine from 2011/2012, one from 2012/ 2013). We thus compared PBDE concentrations in perinatal and nonperinatal milk collected from the same individuals, typically 6 weeks apart. There was no significant difference in individual PBDE congener concentrations between perinatal and nonperinatal milk (Figure 4). On average, fur seals 
accumulated similar BDE concentrations during their winter migration and feeding away from Cape Shirreff as they did while foraging offshore Cape Shirreff's breeding beaches. This implies that within their breeding area and foraging region PBDEs are present in similar concentrations and/or the importance of mobilizing PBDEs from their lipid reserves while at Cape Shirreff.

The average values mask a wide range of individual changes in PBDE concentrations (note large standard deviations in Figure 4). For two fur seals, PBDEs decreased about 2-fold over the course of their foraging trips around Cape Shirreff, whereas it increased for two other seals about 2-fold over this period. Median ratios of nonperinatal divided by perinatal milk were greatest for BDE-183 and BDE-99 implying preferential accumulation of these congeners off Cape Shirreff and/or their less-efficient biodilution within that time period. Overall, profiles of PBDEs in perinatal and nonperinatal milk were very similar (Figure 4), suggesting similar uptake/metabolism of these chemicals in fur seals.

In summary, there is a wide range of trends of $\mathrm{BDE}$ concentrations in individual fur seal milk sampled approximately 9 weeks apart. On the contrary to expectations, there were no significant trends of decreasing concentrations once fur seals started feeding off Cape Shirreff (Figure 4). This might indicate that fur seals, in some years, forage locally prior to coming ashore to give birth.

Phytoplankton. Lipid values in phytoplankton were very low ranging from 0.1 to $6.7 \%$; only samples with lipid values $>0.5 \%$ are presented here to avoid biasing PBDE concentrations high.

Phytoplankton $\sum_{7}$ PBDEs ranged from 3.8 to $320 \mathrm{ng} / \mathrm{g}$ lipid with a mean $\pm S D$ of $53 \pm 76 \mathrm{ng} / \mathrm{g}$ lipid (median of $26 \mathrm{ng} / \mathrm{g}$ lipid, Table S23). BDE-47 and -99 were the two most prevalent congeners (Figure 5), with detection 97 and $91 \%$ of the time, respectively. Previously reported PBDE concentrations in plankton in 2005 were $2-3$ times lower (Table 1). ${ }^{5}$ Macroalgae in the Canadian Arctic similarly contained $\sum_{15}$ PBDEs at 320 ng/g lipid. ${ }^{11}$

Stable isotope analysis of $\delta^{15} \mathrm{~N}$ on phytoplankton samples resulted in a wide range of values from -1.1 to $6.1 \%$. We note that although the dominant composition of the plankton samples were identified as phytoplankton (i.e., diatoms or Phaeocystis sp.), samples may have some microzooplankton present despite efforts to remove any nonphytoplankton species. The $\delta^{13} \mathrm{C}$ values of phytoplankton also had a large range, spanning from -33 to $-19 \%$, with a mean of $-29 \pm$ $0.61 \%$ (median of $-31 \%$ ).

Phytoplankton Trends. Few significant correlations were detected between PBDE phytoplankton concentrations and $\delta^{15} \mathrm{~N}$ values except for the $2010 / 2011$ season, where almost all congeners detected showed a negative trend of decreasing concentration with increasing $\delta^{15} \mathrm{~N}$ value. BDE-47, -100, -99, $-154,-153$, and $\sum_{7}$ PBDEs versus $\delta^{15} \mathrm{~N}$ all had significantly negative trends $(p<0.05)$.

Correlations of phytoplankton PBDE concentrations versus sampling time were only significant for the 2010/2011 sampling season, in which all congeners with $>30 \%$ detection (BDE-28, -49, -47, -100, -99, -154, -153, and $\sum_{7}$ PBDEs) have significantly negative trends; i.e., PBDE concentrations decreased toward the end of austral summer $(p<0.05)$. The austral summer 2010/2011 sampling season, spanning the period from December to March, was longer than the 2007/ 2008 or 2009/2010 seasons. The temporal trend in the 2010/
2011 austral summer may reflect a spike in concentrations picked up from the snow/ice melt early in the austral summer, with either a fading signal or dilution occurring as the season progressed. Legacy organic contaminants (e.g., PCBs, DDT, polycyclic aromatic hydrocarbons) have been detected in snow packs and glacial ice from both Arctic and Antarctic environments, and it has been proposed that in colder regions, where the timing of the melt may be more concentrated as compared to a temperate environment, there is a stronger pulse of organic contaminants released to the surrounding water column. ${ }^{36}$ Chiuchiolo et al. in 2004 detected various OCPs and BDEs (-47, -99, and -100) in phytoplankton and suggested that phytoplankton incorporated POPs from snow and ice melt. Furthermore, POPs may be removed from the water column via sedimentation and organic carbon particle export, which occurs in a relatively short time following phytoplankton blooms in this region (i.e., December and January). ${ }^{5}$ Additionally, Geisz et al. in 2008 present further evidence of glacial meltwater acting as a source of, at least, DDT to the Antarctic marine food web. ${ }^{24}$

There was a significant difference $(p<0.05$, one-tailed twosample $t$ test assuming unequal variances) between diatoms and Phaeocystis for BDE-28, -47, -100, -153, and $\sum_{7}$ PBDEs, with Phaeocystis sp. having greater mean concentrations than diatoms. Similarly, the mean PBDE concentrations in phytoplankton $\left(\delta^{15} \mathrm{~N}\right.$ values $<2 \%$ ) were greater than the mean of phytoplankton with possibly greater microzooplankton contamination $\left(\delta^{15} \mathrm{~N}\right.$ values $>2 \%$ ) for BDE-153 $(p=0.036)$ and with lower significance for $\sum_{7}$ PBDEs $(p=0.059)$.

Krill. Average lipid \% in krill ranged from 14 to $33 \%$, much greater than for phytoplankton. PBDEs were detected in all krill samples, with lower concentrations and less variation in contaminant concentrations than was observed for phytoplankton. The average $\sum_{7}$ PBDEs ranged from 0.14 to $3.5 \mathrm{ng} / \mathrm{g}$ lipid with a mean $\pm \mathrm{SD}$ of $0.61 \pm 0.57 \mathrm{ng} / \mathrm{g}$ lipid (median of 0.49 $\mathrm{ng} / \mathrm{g}$ lipid). BDE-47 was the dominant congener present in all size classes of krill, averaging around $70 \%$ of the total composition (Table S24, SI), followed by BDE-28 and -99, respectively. For $\sum_{7} \mathrm{PBDEs}$, juvenile krill $(n=9)$ had the highest concentrations among E. superba age classes with a mean of $0.65 \pm 0.27 \mathrm{ng} / \mathrm{g}$ lipid, followed by adult krill $(n=18)$ with a mean of $0.51 \pm 0.78 \mathrm{ng} / \mathrm{g}$ lipid, and gravid krill $(n=7)$ with a mean of $0.35 \pm 0.19 \mathrm{ng} / \mathrm{g}$ lipid (Figure S2). The two Thysanoessa sp. krill samples displayed fairly high concentrations at $\sum_{7}$ PBDEs of 1.2 and $0.66 \mathrm{ng} / \mathrm{g}$ lipid. Previously reported PBDE concentrations in krill in 2005 were at least 10 times greater than what we measured, possibly indicating contamination (Table 1$).^{5}$

Stable isotope analysis was performed on a subset of each size class of krill, with the exception of Thysanoessa sp. The $\delta^{15} \mathrm{~N}$ values (mean $\pm \mathrm{SD}$ ) were similar among the different size classes: $4.0 \pm 0.58 \%$ o for juvenile krill, $4.2 \pm 0.19 \%$ o for adult krill, and $4.1 \pm 0.43 \%$ o for gravid krill. There was slightly more variability for $\delta^{13} \mathrm{C}$ values among the krill age classes; $\delta^{13} \mathrm{C}$ values (mean $\pm \mathrm{SD}$ ) were: $-24 \pm 1.41,-25 \pm 0.47$, and $-23 \pm$ $0.68 \%$ for juvenile, adult, and gravid krill, respectively.

Trends of Krill. No significant relationships were found between krill concentration and $\delta^{13} \mathrm{C}$ or $\delta^{15} \mathrm{~N}$ value. No significant differences $(p<0.05)$ were found between krill concentration means from the two sampling years of 2007/ 2008 and 2010/2011 (Figure 5). When comparing different size classes of krill (i.e., juveniles vs adults, adults vs gravid, gravid vs Thysanoessa sp.), BDE-47 and $\sum_{7}$ PBDEs were both 
found to be significantly higher in juveniles than adults $(p<$ $0.05)$.

Fish. Lipid values in fish ranged from 22 to $52 \%$. PBDEs were not detected in any of the five fish samples. Low masses of BDE-47 and -99 (0.1-0.2 ng/sample) were initially determined, however, after blank corrections, all PBDEs in fish samples were <LOD (Table 1). Previous studies have detected PBDEs in Antarctic fish samples, though they have generally been able to extract larger amounts of tissue. ${ }^{3,4,9,10,37,38}$ The total ranges of $\delta^{15} \mathrm{~N}$ and $\delta^{13} \mathrm{C}$ values for fish samples were 9.2 to 11 and -24 to $-21 \%$, correspondingly. For the myctophid fish species, the mean $\pm \mathrm{SD}$ of $\delta^{15} \mathrm{~N}$ values was $9.5 \pm 0.42$ and -24 $\pm 0.24 \%$ o for $\delta^{13} \mathrm{C}$. In comparison, the mean \pm SD of Antarctic silverfish $\delta^{15} \mathrm{~N}$ and $\delta^{13} \mathrm{C}$ values were both higher $(11 \pm 0.63$ and $-21 \pm 1.1 \%$, respectively) than those of the myctophid fish species.

\section{IMPLICATIONS}

Biota from other parts of the world, primarily regions closer to industrialized areas, have started to see a reduction in PBDE concentrations as a reflection of their phase-out. ${ }^{17,18,30,32}$ Time trends of PBDEs in Antarctic biota strongly demonstrate that a decrease of PBDE concentrations in Antarctic biota over the last decade has not (yet) occurred. These surprising results indicate the need for further research to see if and when PBDE concentrations in the Antarctic will start declining as reported in the Arctic. Similarly, the phase-out of PBDEs has led to various novel flame retardants being detected in the environment. ${ }^{39,40}$ As of yet, it is unclear whether these new flame retardants have been transported to Antarctica and have been accumulating in Antarctic biota. This will be an important research area in the near future.

Comparing trends of PBDEs in milk from randomly selected fur seals over several years were by and large similar to trends of the same fur seals milked years apart. Results show that there are large variations in PBDE trends in individuals over time, highlighting the need for large sample sets to determine representative trends. A better understanding of time trends in individual seals is warranted but would require a concerted effort to resample the same individuals over several years, ideally collecting both perinatal and nonperinatal milk.

The high concentrations of PBDEs in phytoplankton compared to the upper trophic level Antarctic fur seal were unexpected but not unprecedented and illustrate the complexity of the Antarctic food web and sampling under challenging circumstances (Table S25). For the phytoplankton sample collections on board a ship, we cannot rule out the possibility of contamination by PBDEs during sampling. ${ }^{41,42}$ Trends of PBDEs in biota are further complicated by the presence of point sources, such as snow and ice melt, which can release pollutant pulses in the austral summer. Finally, the differences in geographic sampling of biota (which were logistically constrained) and the migratory nature and diverse diet of Antarctic fur seals further add complexity to understanding PBDE trends in biota. Monitoring emerging pollutants in remote regions, such as Antarctica, can highlight important global trends of contaminants of concern and further our understanding of long-range transport and global response times to pollutant dynamics.

\section{ASSOCIATED CONTENT}

\section{Supporting Information}

The Supporting Information is available free of charge on the ACS Publications website at DOI: 10.1021/acsomega.8b00440.

Additional details related to sample IDs, chemical analysis, and concentrations of PBDEs (PDF)

\section{AUTHOR INFORMATION}

\section{Corresponding Author}

*E-mail: rlohmann@uri.edu. Phone: 401-874-6612. Fax: 401874-6811.

ORCID $\odot$

Rainer Lohmann: 0000-0001-8796-3229

\section{Present Addresses}

${ }^{\nabla}$ Department of Environmental Sciences, Faculty of Science, Alexandria University, 21511 Moharam Bek, Alexandria, Egypt (M.K.).

${ }^{\#}$ University of California Santa Cruz, 1156 High Street, Santa Cruz, California 95064, United States (E.K.B.).

\section{Notes}

The authors declare no competing financial interest.

${ }^{\perp}$ Author is deceased.

\section{ACKNOWLEDGMENTS}

R.L. acknowledges funding from the National Science Foundation (ANT 1332492) to understand emerging pollutant dynamics in the Antarctic. We acknowledge Hugh Ducklow (LDEO) and the National Science Foundation Palmer LTER (PLR 1440435) for intellectual and logistical support and thank Rebecca Dickhut (Virginia Institute of Marine Science) for her prior leadership on this grant. We thank Dr. Deborah Steinberg, Kate Ruck (Virginia Institute of Marine Science), and Dr. Heidi Geisz (Florida State University) for sample collection. We are grateful to the many field assistants that helped in capture and sample collection of fur seal milk, especially G.I. McDonald, Y. Tremblay, J. Lyons, R. Burner, R. Buchheit, N. Pussini, C. Bonin, and K. Pietrzak. We are also grateful for the support of Drs. Rennie S. Holt and George Watters, directors of the USAMLR program, and to Dr. D.P. Costa, UCSC for their support of Pinniped research at Cape Shirreff. All Antarctic fur seal research and sample collection were conducted under Marine Mammal Protection Act Permit Nos. 1024, 774-1649, 774-1847, and 16472-01 granted by the Office of Protected Resources, National Marine Fisheries Service.

\section{REFERENCES}

(1) Council of Managers of National Antarctic Programs (COMNAP). Antarctic Facilities List. https://www.comnap.aq/ Members/SiteAssets/SitePages/Home/COMNAP Antarctic Facilities List 31 March 2017.xlsx.

(2) Wania, F.; MacKay, D. Tracking the distribution of persistent organic pollutants. Environ. Sci. Technol. 1996, 30, 390A-396A.

(3) Borghesi, N.; Corsolini, S.; Focardi, S. Levels of polybrominated diphenyl ethers (PBDEs) and organochlorine pollutants in two species of Antarctic fish (Chionodraco hamatus and Trematomus bernacchii). Chemosphere 2008, 73, 155-160.

(4) Corsolini, S.; Covaci, A.; Ademollo, N.; Focardi, S.; Schepens, P. Occurrence of organochlorine pesticides (OCPs) and their enantiomeric signatures, and concentrations of polybrominated diphenyl ethers (PBDEs) in the Adélie penguin food web, Antarctica. Environ. Pollut. 2006, 140, 371-382. 
(5) Chiuchiolo, A. L.; Dickhut, R. M.; Cochran, M. A.; Ducklow, H. W. Persistent organic pollutants at the base of the Antarctic marine food web. Environ. Sci. Technol. 2004, 38, 3551-3557.

(6) Brault, E. K.; Goebel, M. E.; Geisz, H. N.; Canuel, E. A.; Dickhut, R. M. Inter-Annual Variation of Persistent Organic Pollutants (POPS) in an Antarctic Top Predator Arctocephalus gazella. Environ. Sci. Technol. 2013, 47, 12744-12752.

(7) Khairy, M. A.; Luek, J. L.; Dickhut, R.; Lohmann, R. Levels, sources and chemical fate of persistent organic pollutants in the atmosphere and snow along the western Antarctic Peninsula. Environ. Pollut. 2016, 216, 304-313.

(8) Vecchiato, M.; Argiriadis, E.; Zambon, S.; Barbante, C.; Toscano, G.; Gambaro, A.; Piazza, R. Persistent Organic Pollutants (POPs) in Antarctica: Occurrence in continental and coastal surface snow. Microchem. J. 2015, 119, 75-82.

(9) Cincinelli, A.; Martellini, T.; Pozo, K.; Kukucka, P.; Sáňka, O.; Corsolini, S. Trematomus bernacchii as an indicator of POP temporal trend in the Antarctic seawaters. Environ. Pollut. 2016, 217, 19-25.

(10) Hale, R. C.; Kim, S. L.; Harvey, E.; La Guardia, M. J.; Mainor, T. M.; Bush, E. O.; Jacobs, E. M. Antarctic research bases: local sources of polybrominated diphenyl ether (PBDE) flame retardants. Environ. Sci. Technol. 2008, 42, 1452-1457.

(11) Wild, S.; McLagan, D.; Schlabach, M.; Bossi, R.; Hawker, D.; Cropp, R.; King, C. K.; Stark, J. S.; Mondon, J.; Nash, S. B. An Antarctic research station as a source of brominated and perfluorinated persistent organic pollutants to the local environment. Environ. Sci. Technol. 2015, 49, 103-112.

(12) Hale, R. C.; Alaee, M.; Manchester-Neesvig, J. B.; Stapleton, H. M.; Ikonomou, M. G. Polybrominated diphenyl ether flame retardants in the North American environment. Environ. Int. 2003, 29, 771-779.

(13) United Nations Environment Programme. The New POPs, 2018. http://www.wipo.int/edocs/lexdocs/treaties/en/unep-pop/trt unep_pop_2.pdf (accessed May 2, 2018).

(14) Hites, R. A. Critical Review Polybrominated Diphenyl Ethers in the Environment and in People: A Meta-Analysis of Concentrations. Environ. Sci. Technol. 2004, 38, 945-956.

(15) Abbasi, G.; Buser, A. M.; Soehl, A.; Murray, M. W.; Diamond, M. L. Stocks and Flows of PBDEs in Products from Use to Waste in the U.S. and Canada from 1970 to 2020. Environ. Sci. Technol. 2015, 49, 1521-1528.

(16) Sacks, V. P.; Lohmann, R. Freely dissolved PBDEs in water and porewater of an urban estuary. Environ. Pollut. 2012, 162, 287-293.

(17) Darnerud, P.; Lignell, S.; Aune, M.; Isaksson, M.; Cantillana, T.; Redeby, J.; Glynn, A. Time trends of polybrominated diphenylether (PBDE) congeners in serum of Swedish mothers and comparisons to breast milk data. Environ. Res. 2015, 138, 352-360.

(18) Airaksinen, R.; Hallikainen, A.; Rantakokko, P.; Ruokojarvi, P.; Vuorinen, P. J.; Parmanne, R.; Verta, M.; Mannio, J.; Kiviranta, H. Time trends and congener profiles of PCDD/Fs, PCBs, and PBDEs in Baltic herring off the coast of Finland during 1978-2009. Chemosphere 2014, 114, 165-171.

(19) Crimmins, B. S.; Pagano, J. J.; Xia, X.; Hopke, P. K.; Milligan, M. S.; Holsen, T. M. Polybrominated Diphenyl Ethers (PBDEs): Turning the Corner in Great Lakes Trout 1980-2009. Environ. Sci. Technol. 2012, 46, 9890-9897.

(20) Corsolini, S.; Borghesi, N.; Schiamone, A.; Focardi, S. Polybrominated diphenyl ethers, polychlorinated dibenzo-dioxins, -furans, and -biphenyls in three species of Antarctic penguins. Environ. Sci. Pollut. Res. 2007, 14, 421-429.

(21) Kelly, B. C.; Ikonomou, M. G.; Blair, J. D.; Gobas, F. A. P. C. Bioaccumulation behaviour of polybrominated diphenyl ethers (PBDEs) in a Canadian Arctic marine food web. Sci. Total Environ. 2008, 401, 60-72.

(22) Polito, M. J.; Goebel, M. E. Investigating the use of stable isotope analysis of milk to infer seasonal trends in the diets and foraging habitats of female Antarctic fur seals. J. Exp. Mar. Biol. Ecol. 2010, 395, 1-9.

(23) Brault, E. Evaluating Persistent Organic Pollutants (POPs) and Mercury in the West Antarctic Peninsula (WAP) Food Web, with a
Focus on Antarctic Fur Seals (Arctocephalus gazella). M.S. Thesis, Virginia Institute of Marine Sciences, Gloucester Point, VA, 2012.

(24) Geisz, H. N.; Dickhut, R. M.; Cochran, M. A.; Fraser, W. R.; Ducklow, H. W. Melting glaciers: A probably source of DDT to the Antarctic marine ecosystem. Environ. Sci. Technol. 2008, 42, 39583962.

(25) Bengtson Nash, S. M.; Poulsen, A. H.; Kawaguchi, S.; Vetter, W.; Schlabach, M. Persistent organohalogen contaminant burdens in Antarctic krill (Euphausia superba) from the eastern Antarctic sector: A baseline study. Sci. Total Environ. 2008, 407, 304-314.

(26) Galbán-Malagón, C. J.; Hernán, G.; Abad, E.; Dachs, J. Persistent organic pollutants in krill from the Bellingshausen, South Scotia, and Weddell Seas. Sci. Total Environ. 2018, 610-611, 14871495.

(27) Corsolini, S.; Ademollo, N.; Martellini, T.; Randazzo, D.; Vacchi, M.; Cincinelli, A. Legacy persistent organic pollutants including PBDEs in the trophic web of the Ross Sea (Antarctica). Chemosphere 2017, 185, 699-708.

(28) Cipro, C. V. Z.; Bustamante, P.; Taniguchi, S.; Montone, R. C. Persistent organic pollutants and stable isotopes in pinnipeds from King George Island, Antarctica. Mar. Pollut. Bull. 2012, 64, 26502655.

(29) Trumble, S. J.; Robinson, E. M.; Noren, S. R.; Usenko, S.; Davis, J.; Kanatous, S. B. Assessment of legacy and emerging persistent organic pollutants in Weddell seal tissue (Leptonychotes weddellii) near McMurdo Sound, Antarctica. Sci. Total Environ. 2012, 439, 275-283.

(30) Vorkamp, K.; Riget, F.; Bossi, R.; Dietz, R. Temporal Trends of Hexabromocyclododecane, Polybrominated Diphenyl Ethers and Polychlorinated Biphenyls in Ringed Seals from East Greenland. Environ. Sci. Technol. 2011, 45, 1243-1249.

(31) de Wit, C. A.; Herzke, D.; Vorkamp, K. Brominated flame retardants in the Arctic environment - trends and new candidates. Sci. Total Environ. 2010, 408, 2885-2918.

(32) Braune, B. M.; Letcher, R. J.; Gaston, A. J.; Mallory, M. L. Trends of polybrominated diphenyl ethers and hexabromocyclododecane in eggs of Canadian Arctic seabirds reflect changing use patterns. Environ. Res. 2015, 142, 651-661.

(33) Alaee, M.; Arias, P.; Sjodin, A.; Bergman, Å. An overview of commercially used brominated flame retardants, their applications, their use patterns in different countries/regions and possible modes of release. Environ. Int. 2003, 29, 683-689.

(34) Arthur, B.; Hindell, M.; Bester, M.; De Bruyn, P. J. N.; Trathan, P.; Goebel, M.; Lea, M.-A. Winter habitat predictions of a key Southern Ocean predator, the Antarctic fur seal (Arctocephalus gazella). Deep Sea Res., Part II 2017, 140, 171-181.

(35) Beckman, K. B.; Ylitalo, G. M.; Towell, R. G.; Krahn, M. M.; O'Hara, T. M.; Blake, J. E. Factors affecting organochlorine contaminant concentrations in milk and blood of northern fur seal (Callorhinus ursinus) dams and pups from St. George Island, Alaska. Sci. Total Environ. 1999, 231, 183-200.

(36) Wania, F.; Ho, J. T.; Jia, C. Q.; Mackay, D. The effects of snow and ice on the environmental behaviour of hydrophobic organic chemicals. Environ. Pollut. 1998, 102, 25-41.

(37) Lana, N. B.; Berton, P.; Covaci, A.; Ciocco, N. F. N. F.; BarreraOro, E.; Atencio, A. A.; Altamirano, J. C. Fingerprint of persistent organic pollutants in tissues of Antarctic notothenioid fish. Sci. Total Environ. 2014, 499, 89-98.

(38) Borghesi, N.; Corsolini, S.; Leonards, P.; Brandsma, S.; de Boer, J.; Focardi, S. Polybrominated diphenyl ether contamination levels in fish from the Antarctic and the Mediterranean Sea. Chemosphere 2009, 77, 693-698.

(39) Hoh, E.; Hites, R. A. Brominated flame retardants in the atmosphere of the east-central United States. Environ. Sci. Technol. 2005, 39, 7794-7802.

(40) Ma, Y.; Salamova, A.; Venier, M.; Hites, R. A. Has the PhaseOut of PBDEs Affected Their Atmospheric Levels? Trends of PBDEs and Their Replacements in the Great Lakes Atmosphere. Environ. Sci. Technol. 2013, 47, 11457-11464. 
(41) Lohmann, R.; Klanova, J.; Kukucka, P.; Yonis, S.; Bollinger, K. Concentrations, fluxes, and residence time of PBDEs across the tropical Atlantic Ocean. Environ. Sci. Technol. 2013, 47, 13967-13975.

(42) Lohmann, R.; Jaward, F. M.; Durham, L.; Barber, J. L.; Ockenden, W.; Jones, K. C.; Bruhn, R.; Lakaschus, S.; Dachs, J.; Booij, K. Potential contamination of shipboard air samples by diffusive emissions of PCBs and other organic pollutants: Implications and solutions. Environ. Sci. Technol. 2004, 38, 3965-3970. 